\title{
Consumer Ethics among Young Consumers in Developing Countries: A Cross National Study
}

Purpose - the present study examined the similarities and differences between young consumers in Indonesia and Thailand based on actionable and strategy-yielding marketing variables (e.g., Machiavellianism, ethical orientations, trust, opportunism, and materialism) and secondly, it examined the impact of these variables on consumer ethics.

Design/methodological/approach - a convenience sample of university students from a large private university in Yogyakarta (Indonesia) and a large public university in Chiang Mai (Thailand) were asked to complete a survey that incorporated scales to measure consumers' ethical beliefs, specifically, Machiavellianism, ethical orientation, opportunism, trust, and materialism, as well as demographic classification questions.

Findings - the findings showed that young Indonesian and Thai consumers display similarities on most of the constructs. Moreover, the study found that personal moral philosophies (i.e., idealism and relativism) and trust strongly influence their judgment in ethically intense situations in both countries.

Research limitation - the current study has several limitations, especially the use of convenience sampling that may limit the generalizability of the findings. Students in Indonesia and Thailand may behave differently from general consumers or other cohorts with regards to their ethical judgments.

Practical implications - therefore, since personal ethical positions are developed over a lifetime of experiences in dealing with and resolving moral issues (Forsyth, et al. 2008), schools and universities should intervene and educate youth on acting in ways that are consistent with moral rules. Currently, universities and schools in Indonesia and Thailand and many other countries in developing countries do not promote this knowledge to students.

Originality - this is one of the first studies exploring consumer ethics in Indonesia and Thailand.

Keywords - consumer ethics, Machiavellianism, Ethical position, Materialism, Trust, Opportunism, Youth, Developing country, Indonesia, Thailand

Paper type - research paper 


\section{Introduction}

A report suggests that Asia is the worst offender in software piracy and the largest source of counterfeit and pirated products (The Economist 2001; OECD 2007). Indonesia and Thailand are two of 13 countries that the United States considers to be the most serious violators of intellectual property rights (Bangkok Post 2012). These facts raise concerns and attention toward consumer ethics. The issue of consumer ethics has been extensively studied since the early 1980s (e.g., Al-Khatib et al. 2005; Bucic et al. 2012; Lu and Lu 2010; Polonsky et al. 2001; Swaidan et al. 2003; Vitell and Paolillo 2003; Vitell and Muncy 2005). Despite increasing research on consumer ethics, few have focused on young consumer variables that may be related to consumer ethics, specifically in Asia where 1.0 billion (60 percent) of the world youth population live in this region (Nugent 2006).

The data show that 50 percent of the Indonesian population of 243 million is under 25 years old and 27 percent are under 15 years of age, while 21 percent of the Thailand population of 69 million are under 15 years old (Population Reference Bureau 2012). Globally, the youth generation, Generation Y or Millennials (i.e., those born between 1981 and 2000), is capable of making a strong and potential impact on business practices now and in the future as they spend an average of US\$153-155 billion a year (Euromonitor 2012; Ramly et al. 2008; Bush et al. 2004; Cui et al. 2003). It shows that young consumers are an important segment of today's market due to their number as well as current and future potential spending power (Lazarevic 2012). In addition, young consumers are well educated (Wolburg and Pokrywczynski 2001), live in a materialistically oriented society (Bakewell and Mitchell, 2003), and are more consumption-oriented than previous cohort (O’Donnel 2006), and more aware of the social consequences of the wrong purchase (Fernandez 2009). Moreover, Vitell (2003) suggests that more studies are needed to examine in greater depth the issue of consumer ethics in cross-cultural settings, and more specifically, to investigate the 
reasons why some ethical consumers behave unethically. With regard to young consumers, Kjeldgaard and Askegaard (2006) found that a similar youth culture and ideology exists globally due to globalization and advances in technology. This global similarity extends to identity, consumption, and cultural innovation. TV and Internet have provided the same information with similar influence everywhere (Lazarevic 2002; Yelkur 2002).

Therefore, the present study will examine first, the similarities and differences between young consumers in Indonesia and Thailand based on actionable and strategyyielding marketing variables (e.g., Machiavellianism, ethical orientations, trust, opportunisms, and materialism); and second, the impact of these variables on consumer ethics. Academics and managers may use the results to minimize the adverse impact of counterfeiting and piracy on companies operating in Indonesia and Thailand. In addition, companies may use these findings to systematically investigate and develop marketing strategies to suit their targeted young consumers in these regions.

\section{Literature review}

Consumer ethical perception/ judgment: the dependent variable.

Muncy and Vitell (1992, p. 298) defined consumer ethics as "the moral principles and standards that guide the behaviour of individuals or groups as they obtain, use and dispose of goods and services.” The majority of the empirical work in the area of consumers' ethics has applied a version of Muncy and Vitell's (1992) Consumers Ethics Scale (CES). It consists of four dimensions: actively benefiting from illegal activity, passively benefiting, actively benefiting from questionable but not necessarily illegal activities, and no harm/no-foul activities. CES was initially developed in the United States (US), and it has been widely used in a range of single country and cross-cultural studies. Some of the countries investigated include: Austria (Rawwas 1996), Egypt (Al-Khatib et al. 1995, 1997); European Union: 
Denmark, Germany, Greece, Italy, Portugal, Scotland, Spain, the Netherlands (Polonsky et al. 2001); Hong Kong (Chan et al. 1998; Rawwas et al. 1994); Indonesia (Lu and Lu 2010); Ireland (Rawwas et al. 1995; Rawwas et al. 1998); Middle East (Al-Khatib et al. 2005); South Africa (Higgs-Kleyn 1998); Turkey (Rawwas et al. 2005); and the US (Al-Khatib et al. 1997; Muncy and Eastman 1998; Muncy and Vitell 1992; Swaidan et al. 2003; Vitell et al. 1991). Furthermore, Vitell and Muncy (2005) updated the scales, which now include three new, distinct categories: (1) downloading/buying counterfeit goods, (2) recycling/environmental awareness, and (3) doing the right thing/doing good. The present study adopted the updated scales by Vitell and Muncy (2005).

Factors Determining Consumers’ Ethical Perceptions: Machiavellianism.

A Machiavellian individual is defined as someone who "employs aggressive, manipulative, exploiting, and devious moves in order to achieve personal or organizational objectives. These moves are undertaken according to perceived feasibility with secondary considerations to the feelings, needs, and/or rights of others” (Calhoun 1969, p. 211). Various studies have explored the impact of Machiavellianism on consumers' ethical perception within one or more countries and cultures such as: the US (Vitell et al. 1991); Lebanon and Egypt (Rawwas et al. 1994); the US and Egypt (Al-Khatib et al. 1997); Austria (Rawwas 1996); Japan (Effmeyer et al. 1999); and Saudi Arabia, Oman and Kuwait (Al-Khatib et al. 2005). The conclusions of these studies suggest that Machiavellianism affects consumers' ethical perception. Nevertheless, these studies show inconclusive findings regarding whether Machiavellianism was discriminated across subgroups within a certain culture or country. For example, no significant difference was found between the US consumers and the Egyptian consumers (Al-Khatib et al. 1997); significant but small differences between the Turkish and American samples (Rawwas et al. 2005); and significant differences among consumers of the Gulf countries in terms of their acceptance or rejection of Machiavellianism. Therefore, since 
the focus of this study is on the same generational cohort, the authors predict more crosscultural similarity on variables measured. Thus, it is hypothesized that:

$\mathbf{H}_{1 \mathbf{a}}$ : Perceptions toward Machiavellianism will NOT differ between youth in Indonesia and Thailand.

$\mathbf{H}_{\mathbf{1 b}}$ : Youth in Indonesia with a high level of Machiavellianism are more likely to accept questionable activities than those with a lower level.

$\mathbf{H}_{1 \mathbf{c}}$ : Youth in Thailand with a high level of Machiavellianism are more likely to accept questionable activities than those with a lower level.

\section{Opportunism.}

Williamson (1985, p. 9) defined opportunism as “a lack of candor or honesty in transactions, to include self-interest seeking with guile”. Studies show that humans have a tendency to act opportunistically, wherever it is possible and profitable (John 1984). For example, an individual may conceal some information and fail to fulfil promises or obligations. The essence of opportunism is the element of deceit or dishonesty involved (MacNeil 1982). Steenhaut and Kenhove (2005) found that consumers with high commitment toward the retailer are more likely to tell when they receive too much change. In contrast, less committed consumers are less likely to tell when they receive too much change. Consumers will act differently in a situation, which creates opportunism because "opportunistic behaviour is purposeful behaviour; and, therefore, it is likely to emerge in situations in which the party behaving opportunistically expects a high probability of success from such behaviour. Similarly, opportunistic behaviour is unlikely in situations in which the expectation of success of such behaviour is low” (Joshi and Arnold 1997, p. 824). Consequently, opportunistic individuals will perceive questionable actions as acceptable. Thus, for youth in developing countries, it is hypothesized that:

$\mathbf{H}_{\text {2a: }}$ Perceptions toward opportunism will NOT differ between youth in Indonesia and Thailand. 
$\mathbf{H}_{\mathbf{2 b}}$ : Youth in Indonesia with a high level of opportunism are more likely to accept questionable activities than those with a lower level.

$\mathbf{H}_{\text {2c: }}$ Youth in Thailand with a high level of opportunism are more likely to accept questionable activities than those with a lower level.

Trust

Various studies have analyzed the role of trust in intra-organizational cooperation and coordination (Colquitt et al. 2007; Dyer and Chu 2000; Kramer 1999). In marketing, trust is a crucial factor in the shift from discrete market transaction to continuous exchange relationship (Colquitt et al. 2007; Dwyer et al. 1987). Trust has been defined as "the expectation of ethically justifiable behaviour - that is, morally correct decisions and actions based upon ethical principles of analysis” (Hosmer 1995, p. 380). It involves general beliefs that other people are likely to be reliable, cooperative or helpful and will be beneficial to one’s long term self-interest (Deutsch 1973; Simpson 2007). Studies indicate that lack of trust have been found to impede the adoption of Internet banking in Nigeria and Thailand (Rotchanakitumnuai and Speece 2003; Sukkar and Hasan 2005). Unlike the legal system in developed countries, the legal systems in most developing countries are structurally and legislatively weak. Bank instability in Argentina, rampant fraud and corruption in Nigeria, and an inherent distrust in banks in Mexico all contribute to barriers to banking in these developing countries (Benamati and Serva 2007). Similarly, Indonesian youth generally perceive their government negatively due to their exposure to rampant corruption and bribery (Kemp 2001). The endemic culture of corruption in developing countries such as Indonesia and Thailand has caused a widespread cynicism and lack of trust among their consumer population that is used to officials' dishonesty toward government and corporations (Alatas 1999). Consequently, this translates into how each individual behaves when there is lack of trust among individuals. Therefore, it is hypothesized that:

$\mathbf{H}_{3 \mathbf{a}}$ : Perceptions toward trust will NOT differ between youth in Indonesia and Thailand. 
$\mathbf{H}_{3 \mathbf{b}}$ : Youth in Indonesia with a high level of trust are less likely to accept questionable activities than those with a lower level.

$\mathbf{H}_{3 \mathbf{c}}$ : Youth in Thailand with a high level of trust are less likely to accept questionable activities than those with a lower level.

\section{Ethical orientation (Idealism vs. relativism).}

Forsyth (1980) suggests two evaluative dimensions that have been widely applied to classify an individual's ethical and moral judgments: idealism and relativism. Relativistic individuals are those who "reject the possibility of formulating or relying on universal moral rules when drawing conclusions about moral questions” (p. 175), while idealistic individuals are those who believe that “desirable consequences can, with the right action, always be obtained” (p. 176)”. Idealism and relativism are important sources of ethical discrepancies among individuals (Smith and Quelch 1993). Various studies have analyzed the ethical beliefs of consumers from two or more countries such as Egypt and the US (Al-Khatib et al. 1997); Korea and the US (Lee and Irgy 1999); and Malaysia and the US (Singhpakdi et al. 1999).

In a meta-analytic study, Forsyth, et al. (2008) concluded that the levels of idealism and relativism vary across regions differentiated by exceptionist ethics, subjectivism, and situationism. Exceptionist ethics are beliefs that one should act in ways that are consistent with moral rules, but be open to exceptions and are more common in Western countries. Subjectivism is defined as the belief that individuals' personal value should guide their moral choices. Situationism refers to the belief that individuals should act to secure the best possible consequences despite violating traditional ethical rules and is prevalent in Eastern and Middle Eastern countries. Absolutism is that belief that one should act in ways that are consistent with moral rules with no exception. Specifically, in the context of Asia, Forsyth et al. (2008) suggest that in a perceived religious society, Indonesia and Thailand tend to be categorized as absolutist, higher in idealism and lower in relativism. Many research findings 
show that individual ethical ideology affects individual's perceptions of ethically questionable actions. Idealism is correlated with a higher level of ethicality, while relativism is correlated with a lower level of ethicality (Effmeyer et al. 1994; Lu and Lu 2010; Rawwas et al. 1994). Despite differences in other age groups, young consumers in the same cohort in eastern countries tend to exhibit more similarities. Thus, it is hypothesized that:

$\mathbf{H}_{4 \mathbf{a}}$ Perceptions toward idealism will NOT differ between youth in Indonesia and Thailand.

$\mathbf{H}_{\mathbf{4 b}}$ : Perceptions toward relativism will NOT differ between youth in Indonesia and Thailand.

$\mathbf{H}_{4 \mathbf{c}}$ Youth in Indonesia with a high level of idealism are less likely to agree with questionable activities than those with a lower level.

$\mathbf{H}_{\mathbf{4 d}}$. Youth in Thailand with a high level of idealism are less likely to agree with questionable activities than those with a lower level.

$\mathbf{H}_{4 \mathbf{e}}$. Youth in Indonesia with a high level of relativism are less likely to agree with questionable activities than those with a lower level.

$\mathbf{H}_{4 \mathrm{f}}$. Youth in Thailand with a high level of relativism are less likely to agree with questionable activities than those with a lower level.

\section{Materialism.}

Materialism is defined as a personal value reflecting "a set of centrally held beliefs about the importance of possessions in one's life” (Richins and Dawson 1992, p. 308). It is an orientation focusing on possessions and money for personal happiness in social progress (Ward and Wackmann 1971). Moreover, Fournier and Richins (1991) suggest that for people with a high level of materialism, possessions are central to their lives, where increased consumption will increase their satisfaction with life. Studies also show that materialism is a product of cultural construction and socialization that affects consumers' perception of objects, symbols, and rituals and influences consumer behaviour (de Mooij 1998; Phinney 1992). Therefore, materialism is negatively correlated with people’s higher ethical standards as consumers (Muncy and Eastman 1998; Vitell 2003). Materialism encourages consumers to 
acquire more goods that marketers have provided. Possession may become more important than religion, friends, and other achievements (Muncy and Eastman 1998; Richins and

Dawson 1992). It is seen as an expression of who a person is and how important she/he is (Belk 1985). Thus, young consumers are very concerned about how other people perceive them because of their group and community orientation (Markow 2005). Consequently, it is reflected in their behaviour. Lu and Lu (2010) found that Indonesian youth, a culture with high materialism, were more likely to engage in questionable activities. They tend to bend ethical rules to gain more possession. As youth in Indonesia and Thailand are very receptive to Westernization and globalization, which is evidenced by popular advertisement supporting materialistic consumerism with heavy emphasis on the use of English terms and Caucasian models, young consumers in both countries will exhibit the same level of materialism (Arnett 2002; Watchravesringkan and Dyer 2006/2007). Thus, the present authors make the following hypotheses:

$\mathbf{H}_{5 a}$. Perceptions toward materialism will NOT differ between youth in Indonesia and Thailand.

$\mathbf{H}_{5 \mathbf{b}}$. Youth in Indonesia with a high level of materialism are more likely to agree with questionable activities than those with a lower level.

$\mathbf{H}_{5 c}$. Youth in Thailand with a high level of materialism are more likely to agree with questionable activities than those with a lower level.

\section{Research Methodology}

\section{Background: Indonesia and Thailand}

Indonesia is the world's fourth most populous country, with a population of 243 million, with 27 percent under 15 years old and only six percent aged 65 years and above (Population Reference Bureau 2012). Indonesia’s Gross National Income (GNI) purchasing power parity (PPP) per capita is approximately US\$ 3,720. With regard to religion, 90 percent of 
Indonesians consider themselves Muslim. Poverty remains widespread with 51 percent of their people living on $\$ 2$ per day.

Thailand has a population of 69 million with 21 percent under 15 years of age and nine percent aged 65 years and above. Thailand's GNI PPP per capita is twice as much as Indonesia’s, US\$6,640. Moreover, 95 percent of all Thais are Buddhist with an intact cultural identity as the only country in South-East Asia that has never been colonized (Chirapravati 1996; Population Reference Bureau 2012). An important point deserving reiteration is that, despite a strongly held Islam and Thai-Buddhist philosophy, both young Indonesian and Thai consumers are very receptive to Westernization and modernization (Watcharvesringkan and Dyer 2010).

\section{Data Collection}

A convenience sample of university students from a large private university in Yogyakarta (Indonesia) and a large public university in Chiang Mai (Thailand) were asked to complete a survey that incorporated scales to measure consumers' ethical beliefs, specifically, Machiavellianism, ethical orientation, opportunism, trust, and materialism, as well as demographic classification questions. In order to obtain reliable information from the respondents, established and validated scales were used for the data collection. In Indonesia, of the 350 questionnaires distributed, 297 were valid and useful with a relatively even distribution of 18-24 year-old male and female respondents (i.e., 54.5 percent and 45.5 percent). For Thailand, of the 200 questionnaires delivered, 160 were valid. Most respondents were female (75.6 percent) aged between 18-24 years. SPSS version 19 was used to analyze the data. Translation and back translation procedures were used for both Indonesian and Thailand (Brislin, 1970). 


\section{Measurement of Constructs and Reliability}

All measures used for the current study were adopted from previous research. The main variables are Machiavellianism, relativism, idealism, opportunism, trust, ethical judgment, and materialism (see Table 1). The Consumer Ethics Scale (CES), measuring individual's beliefs regarding 18 consumer situations having ethical implications was developed by Muncy and Vitell (1992). Moreover, Vitell and Muncy (2005) modified the original scale and added new dimensions that measure consumer tendency to download and willingness to recycle products and 'do good'. In the present study, the latest Vitell and Muncy’s (2005) scale was implemented. The new constructs now measure seven dimensions: (1) actively benefiting from illegal activity (ACT); (2) passively benefiting (PAS); (3) actively benefiting from questionable but not necessarily illegal activities; (4) no harm/no foul activities; (5) downloading copyrighted materials/buying counterfeit goods; (6) recycling/environmental awareness; (7) doing the right thing/doing good (see Table 2).

Based on a principal components factor analysis with a Varimax rotation, scales with a factor loading less than 0.4 were deleted. The reliability of the constructs for Indonesia and Thailand fall within the range of 0.416 to 0.928 . Within the Indonesian sample, the no harm/no foul construct produced the lowest Cronbach $\alpha$, which is consistent with findings from previous research., For example, in the European Union sample, the 'actively benefiting from illegal activity’ construct was only 0.406 (Polonsky et al. 2001). In another study, using a sample from Egypt, the 'no harm/no foul' construct was less than 0.50 (Al-Khatib et al. 1997). In addition, the present study's finding revealed that the new 'downloading' scale may, in fact, measure two different behaviours. One is downloading music, which is now getting more attention from the government and businesses; while the other is buying a counterfeit good, which is still quite an acceptable activity in Indonesia and Thailand. In the future, the item scale may need to be separated and further developed. 
Machiavellianism was measured using a twenty-item scale, Mach IV developed by Christie and Geis (1970). The Cronbach alpha of Machiavellianism of the present study was 0.799 (Indonesia) with 19 items and 0.488 (Thailand) with 20 items. For materialism, the value scale has been widely adopted to examine materialism as a facet of consumer behaviour (e.g., Lu and Lu 2010; Burrough and Rindfleisch 2002). A six-item scale from Richins and Dawson (1992) was adopted to examine how materialism is associated with consumer ethics. The Cronbach’s alpha of Materialism was 0.838 (Indonesia) consisted of four items and 0.751 (Thailand) consisted of six items. Moreover, idealism and relativism were assessed using the Ethical Position Questionnaire (EPQ), developed by Forsyth (1980). The EPQ consists of two scales, each containing ten statements, which evaluate idealism and relativism. The Cronbach alpha statistic for idealism was 0.788 (Indonesia) and 0.768 (Thailand), and for relativism, 0.928 (Indonesia) and 0.649 (Thailand).

Opportunism was measured using a five-item scale, developed by Dwyer and Oh (1987). The Cronbach alpha of opportunism was 0.899 (Indonesia) and 0.721 (Thailand). Finally, the trust dimension was measured using a four-item scale also developed by Dwyer and Oh (1987). The Cronbach alpha statistic was 0.873 (Indonesia) and 0.594 (Thailand). All respondents indicated their opinions on these statements in a five-point scale ranging from 1 $=$ strongly disagree to $5=$ strongly agree. Tables 1 and 2 provide a summary of the present study’s scale items and their reliability coefficients.

Insert Table 1 and 2 about Here

\section{Results}

T-test.

Hypotheses $\mathrm{H}_{1 \mathrm{a}}, \mathrm{H}_{2 \mathrm{a}}, \mathrm{H}_{3 \mathrm{a}}, \mathrm{H}_{4 \mathrm{a}}, \mathrm{H}_{4 \mathrm{~b}}$ and $\mathrm{H}_{5 \mathrm{a}}$ were examined by paired sample $t$-tests. The results are shown in Table 3. There were statistically significant differences between youth in Indonesia and Thailand on their perception toward Machiavellianism $\left(\mathrm{M}_{\mathrm{MACH} \_ \text {INDO }}=3.28 \mathrm{vs}\right.$. 
$\left.\mathrm{M}_{\mathrm{MACH} \_ \text {THAI }}=3.26, p<0.01\right)$; materialism $\left(\mathrm{M}_{\mathrm{MAT} \_\mathrm{INDO}}=2.86\right.$ vs. $\mathrm{M}_{\mathrm{MAT}_{-} \mathrm{THAI}}=2.97, p<$ $0.01)$; trust $\left(\mathrm{M}_{\mathrm{TRU} \_\mathrm{INDO}}=3.23\right.$ vs. $\left.\mathrm{M}_{\mathrm{TRU} \_\mathrm{THAI}}=3.18, p<0.05\right)$; and idealism $\left(\mathrm{M}_{\mathrm{IDE} \_\mathrm{INDO}}=\right.$ 4.32 vs. $\mathrm{M}_{\text {IDE_THAI }}=4.44, p<0.01$ ). Therefore, $\mathrm{H}_{1 \mathrm{a}}, \mathrm{H}_{3 \mathrm{a}}, \mathrm{H}_{4 \mathrm{a}}$ and $\mathrm{H}_{5 \mathrm{a}}$ were not supported. However, data analysis indicates no statistically significant differences between Indonesian and Thailand samples on the variables of opportunism and relativism. Both youth have similar perceptions toward opportunism $\left(\mathrm{M}_{\mathrm{OPP}_{-} \mathrm{INDO}}=3.05\right.$ vs. $\left.\mathrm{M}_{\mathrm{OPP} \_\mathrm{THAI}}=3.04\right)$ and relativism ( $\mathrm{M}_{\text {REL_INDO }}=3.48$ vs. $\left.\mathrm{M}_{\mathrm{REL} \_ \text {THAI }}=3.51\right)$. Thus, $\mathrm{H}_{2 \mathrm{a}}$ and $\mathrm{H}_{4 \mathrm{~b}}$ are supported.

Insert Table 3 about Here

\section{Regression Results.}

Hypotheses $\mathrm{H}_{1 \mathrm{~b}}, \mathrm{H}_{1 \mathrm{c}}, \mathrm{H}_{2 \mathrm{~b}}, \mathrm{H}_{2 \mathrm{c}}, \mathrm{H}_{3 \mathrm{~b}}, \mathrm{H}_{3 \mathrm{c}}, \mathrm{H}_{4 \mathrm{c}}, \mathrm{H}_{4 \mathrm{~d}}, \mathrm{H}_{4 \mathrm{e}}, \mathrm{H}_{4 \mathrm{f}}, \mathrm{H}_{5 \mathrm{~b}}$, and $\mathrm{H}_{5 \mathrm{c}}$ examined how Machiavellianism, opportunism, trust, ethical orientation, and materialism influence ethical judgment of Indonesian and Thailand's youth. Tables 4 and 5 provide correlation matrices of independent variables in the two samples under investigation. The hypotheses were analyzed using multiple regression analyses as summarized in Tables 6 and 7. Each table shows eight regression models; most models were statistically significant. The first model explored the activities that youths consider "actively benefiting from illegal action" (ACT). The six independent variables explained 25 percent (Indonesia) of the variance in the dependent variable $\left(R^{2}=0.257\right.$, Indonesia). For Indonesia, materialism $(\beta=-0.103, \mathrm{p}<0.05)$; trust $(\beta=$ - 0.237, $p<0.01)$ and relativism $(\beta=-0.399, p<0.05)$ constructs were statistically significant in this model. The direction of the beta signs show that youth in Indonesia with high levels of materialism and low levels of trust are more likely to accept behaviour that is deemed as actively benefiting from illegal activity. However, relativism was not in the anticipated direction. Nevertheless, Machiavellianism, opportunism and idealism were insignificant predictors of ACT dimension. For Thailand, the six independent variables explained 12 percent of the variance $\left(R^{2}=0.120\right)$. The trust $(\beta=-0.110, p<0.05)$ and relativism $(\beta=$ - 
0.317, $p<0.01$ ) constructs were statistically significant. However, unlike Indonesia, materialism was not statistically significant. The direction of the beta signs also indicates that youth in Thailand with low levels of trust are more likely to accept this behaviour. Similar to Indonesia, Machiavellianism, opportunity and idealism were insignificant predictors of ACT dimension.

The second model examined activities where consumers tend to passively accept and benefit from the seller's mistakes (PAS). For Indonesia, the six independent variables explained 5.3 percent of the variance $\left(R^{2}=0.053\right)$. The trust construct is the only significant antecedent $(\beta=-0.155, p<0.05)$. As predicted, the direction of the beta shows that individuals with low levels of trust are more likely to accept questionable activities that are deemed as passively benefiting consumers. The remaining constructs were not statistically significant. For Thailand, the six independent variables explained 5.8 percent of the variance $\left(R^{2}=0.058\right)$. Similar to Indonesian youth, the trust construct $(\beta=-0.188, p<0.01)$ was also statistically significant and in the anticipated direction. The remaining constructs were not statistically significant. Results indicate that youth in Thailand with high levels of trust are less likely to accept questionable activities that passively benefit consumers.

The third model assessed consumer attitude toward accepting questionable activities but not illegal (QUEST). For Indonesia, the six independent variables explained 5.1 percent $\left(R^{2}=0.051\right)$ of the variance. Trust $(\beta=-0.138, p<0.05)$ and relativism $(\beta=0.196, p<0.01)$ were significant predictors, and in the expected direction. Findings show that youth with low trust and high relativism are more likely to accept questionable activities. For Thailand, the variables explained 3 percent $\left(R^{2}=0.030\right)$ of the variance. Idealism $(\beta=0.096, p<0.05)$ and relativism were significant predictors, and in the anticipated direction. Yet, idealism was not in the expected direction. 
The fourth model investigated whether the six independent variables could predict the no-harm activities. For Indonesia, the variables explained 3.7 percent $\left(R^{2}=0.037\right)$ of the variance. Relativism $(\beta=0.131, p<0.05)$ was the only significant predictor, and in the anticipated direction. For Thailand, Machiavellianism $(\beta=0.116, p<0.05)$ and opportunism $(\beta=0.139, p<0.05)$ were significant predictors. Opportunism was in the anticipated direction, but Machiavellianism was not. Findings indicate that youth in Thailand with low Machiavellianism and high opportunism are more likely to accept no-harm activities.

The fifth and sixth models examined the relative impact of the six independent variables on two activities (i.e., downloading music and buying counterfeits). For Indonesia, none of the independent variables was statistically significant to predict downloading music. However, for buying counterfeits, the six variables explained 10.9 percent $\left(R^{2}=0.109\right)$ of the variance. Machiavellianism $(\beta=0.108, p<0.05)$; trust $(\beta=0.126, p<0.05)$; idealism $(\beta=$ 0.106, $p<0.05)$ and relativism $(\beta=-0.262, p<0.01)$ were found to be associated with buying counterfeits. Machiavellianism and idealism were in the anticipated direction, while trust and relativism were not. These findings suggest that youth in Indonesia with high levels of Machiavellianism and trust, and low levels of idealism and relativism are more likely to buy counterfeit goods. For Thailand, similar to Indonesian youth, none of the variables explained the downloading music dimension. Moreover, with regard to buying counterfeits, the six variables explained 7.8 percent $\left(R^{2}=0.078\right)$ of the variance. Machiavellianism $(\beta=0.102, p<$ 0.05), opportunism $(\beta=0.125, p<0.05)$, and relativism $(\beta=-0.223, p<0.01)$ were three significant antecedents of buying counterfeits. Machiavellianism and opportunism were in the expected direction, while relativism was not. These findings indicate that youth in Thailand with high levels of Machiavellianism, high levels of opportunism, and low levels of relativism are more likely to engage in no-harm activities. 
The seventh model explored consumers' willingness to recycle and support environmentally friendly products. In Indonesia, the variables explained 3.3 percent $\left(R^{2}=\right.$ $0.033)$ of the variance, with trust $(\beta=0.124, p<0.05)$ as the only significant predictor. For Thailand, the variables were not significant predictors. Finally, the eighth model investigated consumers' willingness to do good toward others. For Indonesia, the variables explained 3.3 percent $\left(R^{2}=0.033\right)$ of the variance, with trust as the only significant predictor. The direction was in the anticipated direction. For Thailand, the six variables explained 8.2 percent $\left(R^{2}=0.082\right)$ of the variance. Trust $(\beta=0.232, p<0.05$, idealism $(\beta=-0.101, p<0.05)$, and relativism $(\beta=0.121, p<0.05)$ were the significant predictors. Trust was in the anticipated direction, while idealism and relativism were not. Finally, Table 8 shows a summary table of the results testing hypotheses.

\section{Insert Table 6, 7 and 8 about Here}

\section{Discussion}

\section{Conclusions}

First, the present study examined the similarities and differences between young consumers in Indonesia and Thailand based on actionable and strategy- yielding marketing variables. Data revealed mixed results. Nevertheless, despite significant differences, the mean differences between young consumers in Indonesia and Thailand are quite small. Overall, the study found that youth from both countries exhibit high idealism followed by relativism. Moreover, they also exhibit a certain degree of Machiavellianism. Findings indicate that most youth tend to detach themselves and make themselves less emotionally involved with others, and are more likely to accept unethical or questionable activities. This situation can be explained when youth in both countries exhibit less trust toward others. Finally, both consumer youth groups are somewhat neutral toward opportunism and materialism. 
The second objective was to examine the impact of Machiavellianism, opportunism, materialism, trust, idealism, and relativism on consumer ethics. For Indonesia, the lower the trust toward others, the more likely they will accept unethical and questionable activities (i.e., ACT, PAS, QUEST, NOH) except for downloading and buying counterfeit products. Results suggest that downloading and buying counterfeits is still considered acceptable in Indonesia. Conversely, the higher the trust toward others, the more likely these youths will become involved in recycling and doing good. Moreover, relativism affects consumer ethics the most. It negatively affects ACT and $\mathrm{DL}_{2}$, where youth with high relativism are less likely to actively engage in perceived illegal activities and buying counterfeits, but more likely to engage in no harm/no foul activities and deceptive activities that are perceived as legal. Machiavellianism only affects $\mathrm{DL}_{2}$, while materialism only negatively affects ACT. Finally, opportunism does not affect any questionable activities.

For Thailand, trust, idealism, and relativism appeared to affect consumer ethics the most. Findings showed that trust negatively affects ACT and PASS but positively affects GOOD These findings suggest that the more young Thai consumers trust others, the less likely they will become involved in activities deemed as actively benefiting from an illegal activity and passively benefiting at the expense of others. And, conversely, the more they trust others, the more likely they will do well toward others. Furthermore, the results showed that idealism positively affects QUEST but negatively affects REC and GOOD. The higher the idealism of the youth, the more likely they will accept questionable but legal activities and less likely they would recycle and do well toward others. Relativism affects consumer ethics the most; it negatively affects ACT and $\mathrm{DL}_{2}$ but positively affects QUEST and GOOD. The results indicated that the higher the level of relativism, the less likely they would accept illegal activities and buying counterfeit goods, but they are more likely to accept legal questionable activities and more likely to do good toward others. 
The present study showed that Machiavellianism negatively affects NOH but positively affects $\mathrm{DL}_{2}$. Results revealed that the higher the level of Machiavellianism, the less likely they would accept no harm/no harm activities and the more likely they would buy counterfeit goods. Finally, similar to the youth in Indonesia, materialism does not affect consumer ethics.

\section{Implications and Limitations}

The findings of this study have several implications. It showed that personal moral philosophies (i.e., idealism and relativism) strongly influence consumers' judgment in ethically intense situations. Similar to Forsyth, et al.’s (2008) propositions, the moral philosophy of youth in Indonesia and Thailand can be categorized as situationism, where they exhibit high idealism and relativism. They act to secure the best possible consequences even if it violates traditional rules about ethics. Consequently, young consumers in both countries showed greater acceptance of various questionable activities. Therefore, since personal ethical positions are developed over a lifetime of experiences in dealing with and resolving moral issues (Forsyth, et al. 2008), schools and universities should intervene and educate youth on acting in ways that are consistent with moral rules. Currently, universities and schools in Indonesia and Thailand and many other countries in developing countries do not promote this knowledge to students. For example, schools need to teach student about plagiarism and how to avoid it through clear example of plagiarized and non-plagiarized sentences (Prohaska, 2013). Studies showed that giving students explicit instructions and clear examples reduce plagiarism significantly (Barry, 2006; Landau, Druen, \& Arcuri, 2002; Walker, 2008). Another implication is by providing clear ethical codes in each school. Climate encouraging ethical behaviour affects students’ perception on how ethically or nonethically other students are behaving (Caldwell, 2010; Prohaska, 2013). 
Furthermore, the findings indicated that trust affects consumer ethics the most. This could be a consequence of the lack of trust toward government due to rampant corruption. Therefore, businesses targeting young consumers should ensure that trust is established between businesses and consumers. Bad publicity of dishonest corporate behaviour may lead young consumers to behave unethically when patronizing these businesses. Thus, associating companies' products or services with social and ethical attributes such as protecting the environment and paying fair wages would project a positive image of the company to consumers and increase consumers' trust, especially in the context of doing business in developing countries. In addition, companies can be transparent about their mistakes and problems. With the prevalent of social media, instead of hiding the facts, companies can use these channels to inform consumers on what they are currently facing. This will create a culture of honesty among consumers.

Moreover, this study contributes to the exploration of young consumers' ethics in Asia, as they are distinct from the previous generation cohorts. They are the next generation of consumers who will significantly impact businesses. Finally, the current study has several limitations, especially the use of convenience sampling that may limit the generalizability of the findings. First, students in Indonesia and Thailand may behave differently from general consumers or other cohorts with regards to their ethical judgments. Secondly, the present study does not measure the impact of religion and cultural differences. Thus, the present study's focus is on cross-national differences. Further research should include religiosity and cultural differences in order to provide a more in-depth analysis of the impact of other religious and cultural variable that may impact consumer ethics in these countries, and in other countries that are considered to be high on consumer ethical violations. 


\section{References}

Alatas, S.H. (1999). Corruption and the Destiny of Asia. Prentice Hall, Malaysia

Al-Khatib, J.A., Rawwas, M.Y.A. \& Vitell, S.J. (1997). Consumer ethics: a cross-cultural investigation. European Journal of Marketing, 31(11-12), 736-767.

Al-Khatib, J.A., Stanton, A.D. \& Rawwas, M.Y.A. (2005). Ethical segmentation of consumers in developing countries: a comparative analysis. International Marketing Review, 22(2), 225-246.

Arnett, J.J. (2002). The psychology of globalization. The American Psychologist, 57(10), 774-783.

Bakewell, C. \& Mitchell, V. (2003). Generation Y consumer decision-making styles. International Journal of Retail \& Distribution Management, 31(2), 95-106.

Bangkok Post. (2012). Thailand remains on US IP piracy and counterfeit list. http://www.bangkokpost.com/business/economics/291380/thailand-remains-on-us-ip-piracycounterfeit-list. Retrieved 3 October, 2012.

Barry, E. S. (2006). Can paraphrasing practice help students define plagiarism? College Student Journal, 40, 377-384.

Belk, R.W. (1985). Materialism: Trait aspects of living in the material world. The Journal of Consumer Research, 12(3), 265-81.

Benamati, J. \& Serva, M.A. (2007). Trust and distrust in online banking: Their role in developing countries. Information Technology for Development, 13(2), 161-175.

Bezoncon, V. \& Blili, S. (2010). Ethical products and consumer involvement: What's new?. European Journal of Marketing, 44(9), 1305-1321.

Brislin, R. W. (1970). Back-translation for cross-culture research. Journal of Cross-Cultural Psychology, 1, 185-216.

Bucic, T., Harris, J. \& Arli, D. (2012). Ethical consumers among the millenials: A crossnational study. Journal of Business Ethics, DOI 10.1007/a10551-011-1151-z.

Burroughs, J. E. \& Rindfleisch, A. (2002). Materialism and well-being: A conflicting values perspective. Journal of Consumer Research, 29(3), 348-370.

Bush, A.J., Martin, C.A. \& Bush, V.D. (2004). Sports celebrity influence on the behavioural intentions of generation Y. Journal of Advertising Research, 44(1), 108-118. 
Caldwell, C. (2010). A ten-step model for academic integrity: A positive approach for business schools. Journal of Business Ethics, 92, 1-13.

Calhoun, R. P. (1969). Niccoli Machiavelli and the twentieth century administrator. Academy of Management Journal, 12 (June), 205-212

Colquitt, J., Scott., B.A. \& LePine, J.A. (2007). Trust, trustworthiness, and trust propensity: A meta-analytic test of their unique relationships with risk taking and job performance. Journal of Applied Psychology, 92(4), 909-927.

Chirapravati, V. (1996). The blossoming of advertising in Thailand. In K.T. Frith (Ed.), Advertising in Asia: Communication, culture, and consumption (pp. 223-240). Ames, IA: Iowa State University Press.

Choi, C.J., Eldomiaty. T.I. \& Kim, S.W. (2007). Consumer trust, social marketing and ethics of welfare exchange. Journal of Business Ethics, 74, 17-23.

Christie, R. \& Geis, F.L. (1970). Studies in Machiavellianism, Academic Press, New York, NY.

Cui, Y., Trent, E.S. \& Sullivan, P.M. (2003). Cause-related marketing: How generation Y responds. Journal of Retail and Distribution Management, 31(6), 310-320.

Deutsch, M. (1973). The resolution of conflict. New Haven, CT: Yale University Press.

deMooij, M. (1997). Global marketing and advertising: Understanding cultural paradoxes. London: Sage Publications.

Dwyer, F. R., Schurr, P.H. \& Oh, S. (1987). Developing buyer-seller relationships. Journal of Marketing, 51(2), 11-27.

Dwyer, R. \& Oh, S. (1987). Output sector munificence effects on the internal political economy of marketing channels. Journal of Marketing Research, 24(4), 347-58.

Erffmeyer, R.C., Keillor, B.D. \& Le Clair, D.T. (1999). An empirical investigation of Japanese consumer ethics. Journal of Business Ethics, 18, 35-50.

Euromonitor. (2012). Young people drive Indonesia’s convenience store boom.http://blog.euromonitor.com/2012/07/young-people-drive-indonesias-conveniencestore-boom.html. Retrieved 10 October, 2012

Forsyth, D.R. (1980). A taxonomy of ethical ideologies. Journal of Personality and Social Psychology, 39(1), 175-84.

Forsyth, D. R., O’Boyle, Jr., E.H. \& McDaniel, M.A. (2008). East meet west: A metaanalytic investigation of cultural variations in idealism and relativism. Journal of Business Ethics, 83, 813-833. 
Fournier, S. \& Richins, M.L. (1991). Some theoretical and popular notions concerning materialism. Journal of Social Behaviour and Personality, 6(6), 403-413.

Higgs-Kleyn, N. H. (1998). Unethical consumer behaviour: An exploratory investigation. Management Dynamics, 7(1), 35-52.

Hosmer, L. T. (1995). Trust: the connecting link between organizational theory and ethics. Academy of Management Review, 20, 379-400.

John, G. (1984). An empirical investigation of some antecedents of opportunism in marketing channels. Journal of Marketing Research. 21(3), 278-88.

Joshi, A. W. \& Arnold, S.J. (1997). The impact of buyer dependence on buyer opportunism in buyer-seller relationships: The moderating role of relational norms. Psychology and Marketing, 14(8), 823-845.

Kemp, M. (2001). Corporate social responsibility in Indonesia: quixotic dream or confident expectation? Technology. Business and Society Programme Paper no. 6, Geneva. United Nations Research Institute for Social Development.

Kennedy, M.S., Ferrel, L.K. \& LeClair, D.T. (2001). Consumers’ trust of salesperson and manufacturer: An empirical studies. Journal of Business Research 51, 73-86.

Kjeldgaard, D. \& Askegaard, S.. (2006). The glocalization of youth culture: The global youth segment as structures of common difference. Journal of Consumer Research, 33(2), 231247.

Landau, J. D., Druen, P. B., \& Arcuri, J. A. (2002) Methods for helping students avoid plagiarism. Teaching of Psychology, 29, 112-115.

Lazaravic, V. (2012). Young consumers: Insight and ideas for responsible marketers. Young Consumers, 13(1), 45-61.

Lee, D.-J. \& Sirgy, J.M. (1999). The effect of moral philosophy and ethnocentrism on quality-of-life orientation in international marketing: A cross-culture comparison. Journal of Business Ethics, 18(1), 73-89.

Lu, L-J. \& Lu, C-J. (2009). Moral philosophy, materialism and consumer ethics: an exploratory study in Indonesia. Journal of Business Ethics, 94, 193-210.

MacNeil, I. R. (1982). Comments to the Workshop on Transaction Cost Analysis in Marketing (August), Evanston, IL.

Markow, D. (2005). Children reactions to tragedy. Young Consumers: Insight and Ideas for Responsible Marketers, 6(2), 8-10.

Muncy, J. A. \& Vitell, S.J. (1992). Consumer ethics: An investigation of the ethical beliefs of the final consumer. Journal of Business Research, 24, 297-311. 
Muncy, J. A. \& Eastman, J.K. (1998). Materialism and consumer ethics: An exploratory study. Journal of Business Ethics, 17(2), 137-145.

Nicholl, A.J. (2002). Strategic options in fair trading retailing', International Journal of Retail and Distribution Management', 30, 6-17.

Nugent, R. (2006). Youth in global world. From http://www.prb.org/pdf06/YouthInAGlobalWorld.pdf. Retrieved 10 January 2013.

OECD. (2007). The economic impact of counterfeiting and piracy. From

http://www.oecd.org/industry/industryandglobalisation/38707619.pdf. Retrieved 5 October 2012.

O’Donnell, J. (2006). Gen Y sits on top of consumer food chain: they're savvy shoppers with money and influence. USA Today, 11 October, 3B.

Phinney, J.S. (1992). The multi-group ethnic identity measure: A new scale for use with adolescents and youth adults from diverse groups. Journal of Adolescent Research, 7, 156176.

Polonsky, M.J., Brito, P.Q., Pinto, J. \& Higgs-Kleyn, N. (2001). Consumer ethics in the European union: a comparison of northern and southern views. Journal of Business Ethics, 31(May II), 117-130.

Population Reference Bureau. (2010). United States and International Profiles. http://www.pbr.org. Retrieved: 5 July 2012.

Prohaska, V. (2013). Encouraing student's ethical behavior. Pscyhological Teacher Network, May. Source: http://www.apa.org/ed/precollege/ptn/2013/05/ethical-behavior.aspx. Retrieved 23 September 2013.

Ramly, Z., Lau, T.C. \& Choe, K.L. (2008). Religiosity as a predictor of consumer ethical behaviour: Some evidence from young consumers from Malaysia. Journal of Business Systems, Governance and Ethics, 3(4), 43-56.

Rawwas, M.Y.A., Vitell, S.J. \& Al-Khatib, J.A. (1994). Consumer ethics: the possible effects of terrorism and civil unrest on the ethical values of consumers. Journal of Business Ethics, 13(3), 223-31.

Rawwas, M.Y.A., Patzer, G.L \& Klassen, M.L. (1995). Consumer ethics in cross-cultural settings: Entrepreneurial implications. European Journal of Marketing, 29(7), 62-78.

Rawwas, M.Y.A. (1996). Consumer ethics: An empirical investigation of ethical beliefs of Austrian consumers. Journal of Business Ethics, 15(9), 1009-1119.

Rawwas, M.Y.A, Patzer, G.J. \& Vitell, S.J. (1998). A cross-cultural investigation of the ethical values of consumers: The potential effect of civil war and civil disruption. Journal of Business Ethics, 17(4), 435-448. 
Rawwas, M.Y.A., Swaidan, S. \& Oyman, M. (2005). Consumer ethics: A cross-cultural study of the ethical beliefs of Turkish and American consumers. Journal of Business Ethics, 57, 183-195.

Richins, M.L. \& Dawson, S.A. (1992). Consumer values orientation for materialism and its measurement: Scale development and validation. Journal of Consumer Research, 19(3), 303316.

Rotchanakitumnuai, S. \& Speece, M. (2003). Barriers to internet banking adoption: A qualitative study among corporate customers in Thailand. International Journal of Bank Marketing, 21, 6/7.

Simpson, J.A. (2007). Psychological foundations of trust. Association for Psychological Science, 16(5), 264-268.

Smith, N.C. \& Quelch, J.A. (1993). Ethics in Marketing (Richard D. Irwin, Homewood, Boston, MA).

Steenhaut, S. \& Kenhove, P.V (2005). Relationship commitment and ethical consumer behaviour in a retail setting: The case of receiving too much change at the checkout. Journal of Business Ethics, 56, 335-353.

Sukkar, A.A., \& Hasan, H. (2005). Toward a model for the acceptance of internet banking indeveloping countries. Information Technology for Development, 11(4).

Swaidan, Z., Vitell, S.J. \& Rawwas, M.Y.A. (2003). Consumer ethics determinants of ethical beliefs of African Americans. Journal of Business Ethics, 46, 175-186.

The Economist. (2001). Phonies galore. http://www.economist.com/node/853362. Retrieved 5 October 2012

The Jakarta Post. (2010). Analysis: how powerful is the young Indonesian consumer?.http://www.thejakartapost.com/news/2010/10/26/how-powerful-youngindonesian-consumer.html. Retrieved 6 October 2012

Vitell, S.J. (2003). Consumer ethics research: Review, synthesis and suggestions for future', Journal of Business Ethics, 43, 33-47

Vitell, S.J., Lumpkin, J.R. \& Rawwas, M.Y.A. (1991). Consumer ethics: An investigation of the ethical beliefs of elderly consumers. Journal of Business Ethics, 11, 365-75.

Vitell, S.J. \& Muncy, J.A. (1992). Consumer ethics: An empirical investigation on factors influencing ethical judgments on the final consumers. Journal of Business Ethics, 11, 585-97.

Vitell, S.J. \& Muncy, J.A. (2005). The Muncy-Vitell consumer ethics scale: A modification and application. Journal of Business Ethics, 62(March), 267-275.

Vitell, S.J. \& Paolillo, J.G.P. (2003). Consumer ethics: The role of religiosity. Journal of Business Ethics, 46, 151-162. 
Ward, S. \& Wackman, D. (1971). Family and media influences on adolescent consumer learning', American Behavioural Scientist 14 (January/February), 415-27.

Watchravesringkan, K. \& Dyer, B. (2006/2007). Materialism among young consumers in China and Thailand: An exploratory study. Alliance Journal of Business Research, 3(1), 2135.

Williamson, O.E. (1985). The Economic Institutions of Capitalism-Firms, Markets, Relationship Contracting. Free Press, New York, NY.

Wolburg, J.M. \& Pokrywczynski, J. (2001). A psychographic analysis of Generation Y college students. Journal of Advertising Research, 41(5), 33-53.

Yelkur, R.(2002). A comparison of buyer behaviour characteristic of US and French generation X', Journal of Euromarketing, 12(1), 5-17. 


\section{Appendices}

Table 1. Scale items

\section{MACHIAVELLIANISM}

Never tell anyone the real reason you did something unless it is useful to do so.

The best way to handle people is to tell them what they want to hear.

One should take action only when sure it is morally right.

Most people are basically good and kind.

It is safest to assume that all people have a vicious streak and it will come out

when they are given a chance.

Honesty is the best policy in all cases.

There is no excuse for lying to someone else.

Generally speaking, people won't work hard unless they're forced to do so.

All in all, it is better to be humble and honest than important and dishonest.

When you ask someone to do something for you, it is best to give the real reason

for wanting it rather than giving reasons that might carry more weight.

Most people who get ahead in the world lead clean, moral lives.

Anyone who completely trusts anyone else is asking for trouble.

The biggest difference between most criminals and other people is that criminals

are stupid enough to get caught.

Most people are brave.

It is wise to flatter important people.

It is possible to be good in all respects.

The saying that there's a sucker born every minute mistakenly underestimates

people.

It is hard to get ahead without cutting corners here and there.

People suffering from incurable diseases should have the choice of being put painlessly to death

People more easily forget the death of their father or mother than the loss of their

property.

\section{OPPORTUNISM}

Other people are not open in their dealings.

Sometimes I have to twist facts a little to get cooperation.

Some amount of manipulation is essential to get the job done.

There is no give and take policy with other people.

We have to be ruthless in our dealings with other people.

\section{MATERIALISM}

It is really true that money can buy happiness.

My dream in life is to be able to own expensive things.

People judge others by the things they own.

I buy some things that I secretly hope will impress other people.

Money is the most important thing to consider in choosing a job.

I think others judge me as a person by the kinds of products and brands I use.

TRUST

I can count on the people to be sincere.

People will not cheat us.

People will generally support us.

People normally fulfil their obligations. 
Table 1 (Cont). Scale items

\begin{tabular}{l|l} 
IDEALISM & Forsyth, 1980
\end{tabular}

A person should make certain that their actions never intentionally harm another even to a small degree.

Risks to another should never be tolerated, irrespective of how small the risks might be.

The existence of potential harm to others is always wrong, irrespective of the benefits to be gained.

One should never psychologically or physically harm another person.

If an action could harm an innocent other, then it should not be done.

Deciding whether or not to perform an act by balancing the positive

consequences of the act against the negative consequences of the act is immoral.

The dignity and welfare of people should be the most important concern in any society.

It is never necessary to sacrifice the welfare of others.

Moral actions are those which closely match the ideals of the most "perfect"' action.

\section{RELATIVISM}

Forsyth, 1980

There are no ethical principles that are so important that they should be a part of any code of ethics.

What is ethical varies from one situation and society to another.

Moral standards should be seen as being individualistic; what one person

considers to be moral may be judged to be immoral by another person.

Different types of moralities cannot be compared as to "rightness".

Questions of what is ethical for everyone can never be resolved since what is

moral or immoral is up to the individual.

Moral standards are simply personal rules which indicate how a person should

behave, and are not to be applied in making judgments of others.

Ethical considerations in interpersonal relations are so complex that individuals should be allowed to formulate their own individual codes.

Rigidly codifying an ethical position that prevents certain types of actions could stand in the way of better human relations and adjustment.

No rule concerning lying can be formulated; whether a lie is permissible or not permissible totally depends on the situation.

Whether a lie is judged to be moral or immoral depends on the circumstances surrounding the action. 
Table 1 (Cont). Scale items

CONSUMER ETHICS

Actively Benefiting

Returning damaged merchandise when the damage is your fault.

Giving misleading price information to a clerk for an unpriced item.

Using a long distance access code that does not belong to you.

Drinking a can of soda in a store without paying it.

Reporting a lost item as stolen to an insurance company in order to collect the money.

Passively Benefiting

Lying about a child's age in order to get a lower price.

Not saying anything when the waitress miscalculates the bill in your favour.

Observing someone shoplifting and ignoring it.

Getting to much change and not saying anything.

Questionable Behaviour

Using an expired coupon for merchandise.

Returning merchandise to a store by claiming it was a gift when it was not.

Using a coupon for merchandise you did not buy.

Not telling the truth when negotiating the price of a new automobile.

Stretching the truth on an income tax return.

No Harm.

Installing software on your computer without buying it

Burning a CD instead of buying it.

Using a computer software or games that you did not buy.

Spending over an hour trying on different dresses and not purchasing any.

\section{Downloading}

Downloading music from the interne instead of buying it

Buying counterfeit goods instead of buying the original manufacturers brands

\section{Recycling}

Buying products labelled as "environmentally friendly" even if they don't work as

well as competing products

Purchasing something made of recycled materials even though it is more expensive

Buying only from companies that have a strong record of protecting the

environment

Recycling materials such as cans, bottles, newspapers etc.

Doing Good

Returning to the store and paying for an item that the cashier mistakenly did not

charge you for

Correcting a bill that has been miscalculated in your favour

Giving a larger than expected tip to a waiter or waitress

Not purchasing products from companies that you believe don't treat their

employees fairly 
Table 2. Reliability of the measures

\begin{tabular}{|l|c|c|c|c|}
\hline \multirow{2}{*}{ Construct } & \multicolumn{2}{|c|}{ Indonesia } & \multicolumn{2}{c|}{ Thailand } \\
\cline { 2 - 5 } & $\begin{array}{c}\text { Number } \\
\text { of items }\end{array}$ & Alpha & $\begin{array}{c}\text { Number } \\
\text { of items }\end{array}$ & Alpha \\
\hline Consumer ethics scale: & & & & \\
\hline • Actively benefiting from illegal activity (ACT) & 2 & 0.678 & 4 & 0.623 \\
\hline • Passively benefiting (PASS) & 2 & 0.893 & 4 & 0.806 \\
\hline$\bullet \quad$ Questionable action (QUEST) & 1 & - & 1 & - \\
\hline - No harm/ no foul (NOH) & 3 & 0.416 & 4 & 0.814 \\
\hline • Downloading (DL): & & & & \\
\hline$\quad$ o Downloading music (DL 1) & 1 & - & 1 & - \\
\hline$\quad$ o Buying counterfeit (DL 2) & 1 & - & 1 & - \\
\hline - Recycling (REC) & 4 & 0.748 & 3 & 0.758 \\
\hline Doing good (GOOD) & 4 & 0.556 & 2 & 0.569 \\
\hline Machiavellianism (MAC) & 19 & 0.799 & 20 & 0.488 \\
\hline Opportunism (OPP) & 5 & 0.899 & 4 & 0.721 \\
\hline Materialism (MAT) & 4 & 0.838 & 6 & 0.751 \\
\hline Trust (TRU) & 4 & 0.873 & 2 & 0.594 \\
\hline Idealism (IDE) & 2 & 0.778 & 4 & 0.768 \\
\hline Relativism (REL) & 5 & 0.928 & 3 & 0.649 \\
\hline
\end{tabular}

Table 3. Examination of the differences between Indonesia and Thailand

\begin{tabular}{|l|c|c|c|c|}
\hline Construct & $\begin{array}{c}\text { Indonesia } \\
\text { Mean } \\
\text { (rank) }\end{array}$ & $\begin{array}{c}\text { Thailand } \\
\text { Mean } \\
\text { (rank) }\end{array}$ & $\boldsymbol{t}$-Value & Significance \\
\hline Machiavellianism (MAC) & $3.28(3)$ & $3.26(3)$ & 7.39 & $\mathbf{0 . 0 0 0}$ \\
\hline Opportunism (OPP) & $3.05(5)$ & $3.04(5)$ & 1.43 & 0.153 \\
\hline Materialism (MAT) & $2.86(6)$ & $2.97(6)$ & -5.57 & $\mathbf{0 . 0 0 0}$ \\
\hline Trust (TRU) & $3.23(4)$ & $3.18(4)$ & 2.24 & $\mathbf{0 . 0 2 6}$ \\
\hline Idealism (IDE) & $4.32(1)$ & $4.44(1)$ & -5.04 & $\mathbf{0 . 0 0 0}$ \\
\hline Relativism (REL) & $3.48(2)$ & $3.51(2)$ & -1.20 & 0.232 \\
\hline
\end{tabular}

Table 4. Correlation matrix of independent variables - Indonesia

\begin{tabular}{|l|c|c|c|c|c|c|}
\hline & MAC & OPP & MAT & TRU & IDE & REL \\
\hline MAC & 1.000 & & & & & \\
\hline OPP & 0.027 & 1.000 & & & & \\
\hline MAT & -0.006 & 0.049 & 1.000 & & & \\
\hline TRU & 0.006 & $-0.306^{* *}$ & -0.037 & 1.000 & & \\
\hline IDE & -0.045 & -0.061 & -0.023 & 0.003 & 1.000 & \\
\hline REL & -0.009 & -0.062 & 0.032 & -0.044 & 0.039 & 1.000 \\
\hline
\end{tabular}

*Significant at $p<0.05$

**Significant at $p<0.01$

Table 5. Correlation matrix of independent variables - Thailand

\begin{tabular}{|l|c|c|c|c|c|c|}
\hline & MAC & OPP & MAT & TRU & IDE & REL \\
\hline MAC & 1.000 & & & & & \\
\hline OPP & $0.167^{*}$ & 1.000 & & & & \\
\hline MAT & $0.163^{*}$ & $0.331^{* *}$ & 1.000 & & & \\
\hline TRU & $0.238^{*}$ & 0.116 & -0.003 & 1.000 & & \\
\hline IDE & 0.125 & $-0.160^{*}$ & -0.119 & $0.162^{*}$ & 1.000 & \\
\hline REL & $0.237^{* *}$ & $0.193^{*}$ & 0.089 & $0.251^{*}$ & 0.028 & 1.000 \\
\hline
\end{tabular}

*Significant at $p<0.05$

**Significant at $p<0.01$ 
Table 6. Determinants of consumer ethics [Indonesia]

\begin{tabular}{|l|l|l|l|l|l|l|l|l|}
\hline & \multicolumn{9}{|c|}{$\boldsymbol{\beta}$ coefficient } \\
\hline Dependent & MAC & OPP & MAT & TRU & IDE & REL & $\boldsymbol{R}^{2}$ & F value \\
\hline ACT & 0.031 & -0.036 & $-0.103^{*}$ & $-0.237^{* *}$ & 0.003 & $-0.399^{* *}$ & 0.257 & $25.263^{* *}$ \\
\hline PAS & -0.015 & 0.064 & -0.081 & $-0.155^{*}$ & -0.023 & -0.080 & 0.053 & $4.056^{*}$ \\
\hline QUEST & -0.012 & 0.004 & -0.015 & $-0.138^{*}$ & -0.010 & $0.196^{* *}$ & 0.051 & $3.913^{*}$ \\
\hline NOH & -0.090 & 0.082 & -0.062 & -0.066 & -0.030 & $0.131^{*}$ & 0.037 & $2.839^{*}$ \\
\hline DL 1 & -0.017 & -0.018 & 0.116 & 0.051 & -0.005 & 0.077 & 0.026 & 1.937 \\
\hline DL 2 & $0.108^{*}$ & 0.080 & 0.050 & $0.126^{*}$ & $-0.106^{*}$ & $-0.262^{* *}$ & 0.109 & $8.925^{* *}$ \\
\hline REC & 0.019 & -0.038 & 0.026 & $0.124^{*}$ & -0.056 & 0.075 & 0.033 & $2.498^{*}$ \\
\hline GOOD & -0.002 & 0.074 & -0.018 & $0.152^{*}$ & -0.008 & 0.085 & 0.033 & $2.472^{*}$ \\
\hline
\end{tabular}

*Significant at $p<0.05$

$* *$ Significant at $p<0.01$

Table 7. Determinants of consumer ethics [Thailand]

\begin{tabular}{|l|l|l|l|l|l|l|l|l|}
\hline & \multicolumn{9}{|c|}{$\boldsymbol{\beta}$ coefficient } \\
\hline Dependent & MAC & OPP & MAT & TRU & IDE & REL & $\boldsymbol{R}^{2}$ & F value \\
\hline ACT & 0.040 & 0.056 & -0.010 & $-0.110^{*}$ & 0.029 & $-0.317^{* *}$ & 0.120 & $10.009^{* *}$ \\
\hline PAS & -0.025 & 0.089 & -0.003 & $-0.188^{* *}$ & 0.052 & -0.037 & 0.058 & $4.474^{* *}$ \\
\hline QUEST & -0.013 & -0.019 & 0.056 & -0.098 & $0.097^{*}$ & $0.120^{*}$ & 0.030 & $2.255^{*}$ \\
\hline NOH & $-0.116^{*}$ & $0.139 *$ & 0.045 & -0.099 & 0.026 & -0.003 & 0.047 & $3.571^{*}$ \\
\hline DL 1 & -0.026 & -0.030 & 0.114 & 0.004 & -0.025 & 0.082 & 0.023 & 1.714 \\
\hline DL 2 & $0.102^{*}$ & $0.125^{*}$ & 0.041 & 0.076 & -0.090 & $-0.223^{*}$ & 0.078 & $6.175^{* *}$ \\
\hline REC & 0.021 & -0.067 & -0.018 & 0.065 & $-0.100^{*}$ & 0.060 & 0.024 & 1.829 \\
\hline GOOD & 0.021 & 0.008 & -0.091 & $0.232^{* *}$ & $-0.101^{*}$ & $0.121^{*}$ & 0.082 & $6.535^{* *}$ \\
\hline
\end{tabular}

*Significant at $p<0.05$

**Significant at $p<0.01$ 
Table 8. A summary table of the hypotheses and results

\begin{tabular}{|c|c|}
\hline Hypotheses & Testing results \\
\hline $\begin{array}{l}\mathbf{H}_{1 \mathbf{a}} \text { : Perception toward Machiavellianism will NOT differ between youths in } \\
\text { Indonesia and Thailand. }\end{array}$ & Not supported \\
\hline $\begin{array}{l}\mathbf{H}_{\mathbf{1 b}} \text { : Youths in Indonesia with a high level of Machiavellianism are more } \\
\text { likely to accept questionable activities than those with a lower level. }\end{array}$ & Partially (1 of 8 ) supported \\
\hline $\begin{array}{l}\mathbf{H}_{1 \mathbf{c}} \text { : Youths in Thailand with a high level of Machiavellianism are more likely } \\
\text { to accept questionable activities than those with a lower level. }\end{array}$ & Partially (2 of 8) supported \\
\hline $\begin{array}{l}\mathbf{H}_{2 \mathrm{a}} \text { Attitude toward opportunism will NOT differ between youths in } \\
\text { Indonesia and Thailand. }\end{array}$ & Supported \\
\hline $\begin{array}{l}\mathbf{H}_{2 \mathbf{b}} \text { Youths in Indonesia with a high level of opportunism are more likely to } \\
\text { accept questionable activities than those with a lower level. }\end{array}$ & Not supported \\
\hline $\begin{array}{l}\mathbf{H}_{2 \mathrm{c} .} \text { Youths in Thailand with a high level of opportunism are more likely to } \\
\text { agree questionable activities than those with a lower level. }\end{array}$ & Partially (2 of 8) supported \\
\hline $\begin{array}{l}\mathbf{H}_{3 \mathrm{a} \cdot} \text { Attitude toward trust will NOT differ between youths in Indonesia and } \\
\text { Thailand. }\end{array}$ & Not supported \\
\hline $\begin{array}{l}\mathbf{H}_{3 \mathbf{b}} \text {. Youths in Indonesia with a high level of trust are less likely to accept } \\
\text { questionable activities than those with a lower level. }\end{array}$ & Partially (6 of 8) Supported \\
\hline $\begin{array}{l}\mathbf{H}_{3 \mathbf{c}} \text {. Youths in Thailand with a high level of trust are less likely to accept } \\
\text { questionable activities than those with a lower level. }\end{array}$ & Partially (3 of 8) Supported \\
\hline $\begin{array}{l}\mathbf{H}_{4 a} \cdot \text { Attitude toward idealism will NOT differ between youths in Indonesia } \\
\text { and Thailand. }\end{array}$ & Not supported \\
\hline $\begin{array}{l}\mathbf{H}_{4 \mathbf{b}} \text {. Attitude toward relativism will NOT differ between youths in Indonesia } \\
\text { and Thailand. }\end{array}$ & Supported \\
\hline $\begin{array}{l}\mathbf{H}_{4 \mathrm{c}} \text {. Youths in Indonesia with a high level of idealism are less likely to agree } \\
\text { with questionable activities than those with a lower level. }\end{array}$ & Partially (1 of 8 ) supported \\
\hline $\begin{array}{l}\mathbf{H}_{4 \mathrm{~d}} . \text { Youths in Thailand with a high level of idealism are less likely to agree } \\
\text { with questionable activities than those with a lower level. }\end{array}$ & Partially (3 of 8) supported \\
\hline $\begin{array}{l}\mathbf{H}_{4 \mathrm{e}} \text {. Youths in Indonesia with a high level of relativism are less likely to agree } \\
\text { with questionable activities than those with a lower level. }\end{array}$ & Partially (4 of 8) supported \\
\hline $\begin{array}{l}\mathbf{H}_{4 \mathrm{f}} \text {. Youths in Thailand with a high level of relativism are less likely to agree } \\
\text { with questionable activities than those with a lower level. }\end{array}$ & Partially (3 of 8) supported \\
\hline $\begin{array}{l}\mathbf{H}_{5 \mathrm{a}} \text {. Attitude toward materialism will NOT differ between youths in Indonesia } \\
\text { and Thailand. }\end{array}$ & Not supported \\
\hline $\begin{array}{l}\mathbf{H}_{5 \mathbf{b}} \cdot \text { Youths in Indonesia with a high level of materialism are more likely to } \\
\text { agree with questionable activities than those with a lower level. }\end{array}$ & Partially (1 of 8 ) supported \\
\hline $\begin{array}{l}\mathbf{H}_{5 \mathbf{c}} \text { Youths in Thailand with a high level of materialism are more likely to } \\
\text { agree with questionable activities than those with a lower level. }\end{array}$ & Not s \\
\hline
\end{tabular}

